\title{
Low back pain status in elite and semi-elite Australian football codes: a cross-sectional survey of football (soccer), Australian-Rules, rugby league, rugby union and non-athletic controls
}

Wayne Hoskins ${ }^{1}$, Henry Pollard ${ }^{1 *}$, Chris Daff', Andrew Odell ${ }^{2}$, Peter Garbutt ${ }^{3}$, Andrew McHardy ${ }^{1}$, Kate Hardy ${ }^{1}$ and George Dragasevic ${ }^{1}$

The journal has been informed by the authors' institution that, contrary to the statement in this article [1], the Macquarie University Human Ethics Committee did not receive an application for ethics approval for this study. As the study was conducted without institutional ethics committee oversight, this article has been retracted.

\footnotetext{
Author details

'Division of Environmental and Life Sciences, Department of Health and Chiropractic, Macquarie University, NSW 2109, Australia. ${ }^{2}$ Norwest Orthopaedic and Sports Physiotherapy, Norwest, NSW 2153, Australia. ${ }^{3}$ Enhance Chiropractic and Massage Sports Injury Centre, Ngunnawal, ACT 2913, Australia.
}

Received: 8 July 2011 Accepted: 13 July 2011 Published: 13 July 2011

\section{Reference}

1. Hoskins Wayne, Pollard Henry, Daff Chris, Odell Andrew, Garbutt Peter, McHardy Andrew, Hardy Kate, Dragasevic George: Low back pain status in elite and semi-elite Australian football codes: a cross-sectional survey of football (soccer), Australian-Rules, rugby league, rugby union and nonathletic controls. BMC Musculoskeletal Disorders 2009, 10:38

Pre-publication history

The pre-publication history for this paper can be accessed here: http://www.biomedcentral.com/1471-2474/12/158/prepub

\section{doi:10.1186/1471-2474-12-158}

Cite this article as: Hoskins et al:: Low back pain status in elite and semi-elite Australian football codes: a cross-sectional survey of footbal (soccer), Australian-Rules, rugby league, rugby union and non-athletic controls. BMC Musculoskeletal Disorders 2011 12:158.

* Correspondence: hpollard@optushome.com.au

'Division of Environmental and Life Sciences, Department of Health and

Chiropractic, Macquarie University, NSW 2109, Australia

Full list of author information is available at the end of the article

Submit your next manuscript to BioMed Central and take full advantage of:

- Convenient online submission

- Thorough peer review

- No space constraints or color figure charges

- Immediate publication on acceptance

- Inclusion in PubMed, CAS, Scopus and Google Scholar

- Research which is freely available for redistribution 